\title{
SELF-HEALING OF CRACKED CONCRETE WITH BACTERIAL APPROACH
}

\author{
الالتحام الأتي للخرسانة المتشرخة باستخدام البكتيريا \\ Magdy A. Zahran, Organic Chemistry Professor, Faculty of Science, El-Menoufia University \\ Magdy Attia, Agricultural Microbiology Professor, National Centre of Research, Egypt
}

Amal A. Nasser, Assistant Professor, Civil Engineering Department, Faculty of Engineering, El-Menoufia University

\begin{abstract}
Self-healing mechanisms are new techniques used to improve structures durability. Two species of Bacteria (Bacillus subtilis and B. megaterium) were added to rich cement pastes. Cement based bacteria were tested under compression. The two mixes were compared with a control mix to study the bacterial effect on cement paste compressive strength. Ferrocement laminates were cast using the bacterial mixes and the control mix. Laminates were tested under flexural loading until failure. Tested laminates were kept moisturized. Laminates were reloaded after two months. Test results showed that bacterially based systems have the ability to heal and restore the material to its original state when damaged. Bacterially based system seems promising and sustainable.

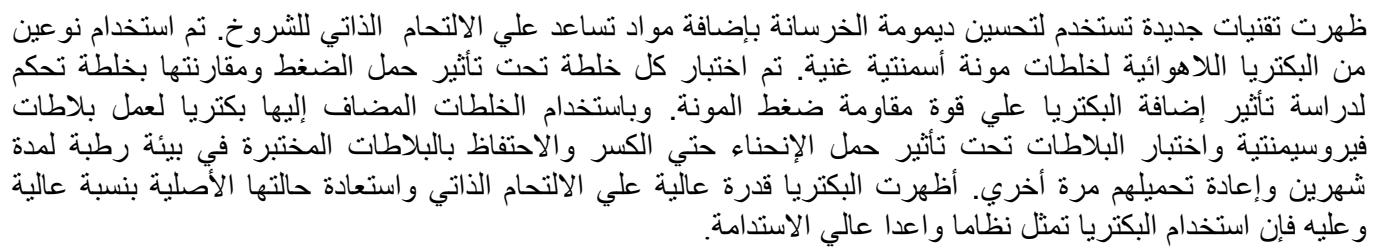

\section{Introduction}

Key Words: Self-healing, Sustainable Concrete, Durability, Bacterial Application, Ferrocement.

In concrete constructions, large cracks hamper structural integrity. Small sized cracks may result in durability problems. Cracks propagation increases matrix permeability. Ingress water and chemicals cause premature matrix degradation and corrosion of embedded steel reinforcement. Regular manual maintenance and repair of concrete constructions is expensive. Inclusion of an autonomous self-healing repair mechanism is beneficial [1,2]. Self-healing mechanisms are new techniques used to improve structures durability. Self-healing materials are polymers, metals, ceramics and their composites. They have the ability to heal and restore the material Lime mortars have a self-healing capacity which contributes the structure's durability. Lime mortar self-healing process is a spontaneous in-situ repair of micro-damage occurred due to weathering or overloading processes. Dissolution, transport and reprecipitation of calcium compounds occur to heal cracks and fissures. Recrystallization of portlandite and subsequent carbonation of $\mathrm{CaCO}_{3}$ are able to self-heal cracks [6]. Old brick buildings were crackhealed in Amsterdam canals. Healing process to its original state when damaged through thermal, mechanical, ballistic or other means. This characteristic effectively expands product/structure lifetime [3].

Asphalt binder is a self-healing material. When two surfaces of an asphalt binder come into contact, they tend to heal or regain strength with respect to time [4]. Healing rates of asphalt courses increase with the temperature. Mastic is made electrically conductive by adding electrically conductive fibers. Bitumen is not aged by the induction heating. It can be repeated many times for samples that are completely broken [5].

contributed dissolution and re-precipitation of calcium carbonate with lime-based mortar matrix [7]. Concrete is a heterogeneous, brittle and porous material. It consists of coarse aggregate, sand and cement paste. In concrete mixtures a residual of the cement is left unhydrated. When concrete cracks, unreacted cement grains become exposed to moisture penetrating the crack. Hydration process may start again and hydration products may fill up and heal the crack at early ages [8]. The low water/binder ratio in 
addition to the large amount of fly ash aids in promoting self-healing via continued hydration and pozzolanic activities. Micro-reservoirs of unhydrated cement and unreacted fly ash in Engineered Cementitious Composites (ECC) ensure self-healing to pervade throughout a structure. ECC is expected to overcome the problem of early age cracking in high performance concrete materials for infrastructures exposed to water. Engineered Cementitious Composites (ECC) is cement-based product, which have a remarkable self-healing capacity, even recovery of the original strength. Products formed inside the cracks are calcites known to be relatively weak. Bridging fibers serve as nucleation sites for the calcite crystals. Fibers act as reinforcements [8, 9].

Self-healing materials have the built-in capability to substantially recover their mechanical properties after damage. Such recovery can occur autonomously and/or be activated after an application of a specific stimulus [10]. Reactions of concrete setting form shrinkage cracks. Concrete structures have a certain capacity for autonomous healing of such micro cracks. High binder content mixtures show remarkable crack-healing properties due to delayed (secondary) hydration of matrix embedded. In traditional high-binder content mixtures, autogenously self-healing of cracks appear limited to cracks with a small width $(<0.2 \mathrm{~mm})$. In massive concrete structures, surface cracks form during the first day of hydration. Cracks are closed due to core cooling down and continuous hydration process $[11$, 12].

Self-healing is achieved in a single fiber polymer matrix composite with high degree of restoration of the original tensile strength. Self-healing composite includes healing agent, catalyst, hollow fiber and The mechanism of crack healing in bacterial concrete presumably occurs through metabolic conversion which results in crack-sealing. This biochemically mediated process resulted in efficient sealing of concrete micro-cracks in wet environments [2]. After cracking, bacteria mixed-in fresh concrete become activated in the presence of water. It starts to multiply and precipitate minerals, such as calcium carbonate. Minerals close the crack [8].

Efficient sealing of surface cracks by mineral precipitation is bacteria-based mixtures sprayed or applied onto damaged surfaces or manually inserted into cracks. Spores of specific alkali-resistant bacteria were added to the concrete mixture as selfhealing agent. These spores germinated after activation by crack ingress water and produced copious amounts of crack-filling calcium carbonate based minerals. They converted precursor organic compounds added to the concrete mixture. Bacteriabased self-healing potential was limited to relatively young (7days curing) concrete only. Viability and related activity of bacterial spores directly resin. Catalyst is placed on the outer surface of the hollow fiber to avoid untimely polymerization. When the hollow fiber breaks due to the propagation of cracks, the healing agent is released. Then, healing agent fills the gap in the fiber and matrix damage zone. Healing of a crack takes place after the healing agent polymerizes. It comes in contact with catalyst on the surface of the fiber [13]. Repair components stored inside hollow tubes or capsules dispersed within the concrete. On cracking, tubes or capsules rupture and release the healing agent. It flows easily out of its container to fill cracks producing tough, highly cross-linked material. Healing agents are cementitious or synthetic materials. Cementitious healing agent needs water, which penetrate into a crack from external sources [8].

Biological systems respond to injury in three stepsnamely inflammatory response (immediate), cell proliferation (secondary), and matrix remodelling (long-term). These processes are similarly mimicked by synthetic (biomimetic) system. Damage in material triggers the second response. Self-healing agents are transferred into damage location, followed by matrix remodeling. The biological analogy of selfhealing materials would be the modification of living tissue and organisms to promote immortality [3]. Self-healing makes use of a porous network concrete. Innovative idea mimics bone shape material and its healing process when injury happens. Prefabricated porous concrete cores were cast internally in the center of concrete cylinder. In terms of morphology, this is similar to bone structure. Comparison both mechanical responses between virgin and healed samples shows that healing took place using the proposed porous network concrete [14].

(unprotected) embedded in the concrete matrix was restricted to about two months [2].

Concrete with low cement content, i.e. based on a high water/cement ratio, will likely not feature a significant autogenous crack-healing capacity as most. Cement particles hadfull hydration during early age. Mineral-producing bacteria improve durability of relatively cheap and environmentally sustainable concrete. Alkaliphilic and endolithic bacteria include calcite-producing bacteria. Particular bacteria originate certain analogy with the concrete matrix, i.e. highly alkaline $\mathrm{pH}$. Bacterial spores directly added to the cement paste mixture remained viable for a period up to 4 months. A continuous decrease in pore size diameter during cement setting probably limited life span of spores as pore widths decreased the typical size of Bacillus spores [1].

\section{Work Objective:}

A high crack-healing potential of concrete structures is beneficial as it makes the material stronger and more durable. Continuous healing reduces premature matrix degradation risk and corrosion of the 
embedded steel reinforcement due to ingress water and aggressive chemicals. Concrete structures have a certain capacity for autonomous healing of such micro cracks. Bacteria and organic bio-mineral precursor compounds are incorporated in the material matrix to obtain an autogenous self-healing concrete.

\section{Experimental Work}

\subsection{MATERIALS}

3.1.1. Sand Fine aggregates: Medium well-graded sand of fineness modulus 2.2 was used for mortar.

3.1.2. Cement: Ordinary Portland cement with grade 32.5N confirmed Egyptian Standard Specifications (ESS) requirements (4756-1/2005).

3.1.3. Water: fresh tap water was used with water/cement ratio 0.5

3.1.4. Reinforcement: Expanded Wire Mesh reinforces laminates. It is locally produced and available in the Egyptian market on commercial scale. One meter square of wire mesh weighs $1.5 \mathrm{~kg}$.

The $\mathrm{pH}$ of this medium was close to 10 . Cultures were aerobically incubated in Erlenmeyer flasks on a in a rotary shaking incubator at $150 \mathrm{rpm}$. Growth and sporulation yield of bacteria was regularly checked and quantified microscopic analysis by using a haemocytometer.

3.1.6. Lactate: Calcium lactate is Fluka product.

3.2. Methods

3.2.1. Bacteria Preparation: Before addition to the paste, cultures containing high number of spores 3.2.2. Mortar Mixes

The mortar mixture was weighed and mixed manually in a batch for ten minutes. Mortars proportions were in accordance to Ferrocement Model Code. Ratio by volume was 1:4 for cement: sand, respectively, and the water/cement ratio of 0.5 . Mortar cubes $(70 \times 70 \times 70 \mathrm{~mm})$ were cast for test specimens.

Compressive strength of cement paste samples were prepared and tested. Test specimens with dimensions of $7 \times 7 \times 7 \mathrm{~cm}$ were cast and tested for compressive
3.1.5. Bacteria:

Selection and cultivation of calcite-producing bacteria

Two species originally isolated from alkaline soil samples, Bacillus subtilis and B. megaterium, were purchased from the Cultural Collection of Agricultural Microbiology Department, National Research Centre, Cairo, Egypt. These bacteria were cultured in liquid media according to the suppliers' recommendations (medium composition: $5 \mathrm{~g}$ peptone, $3 \mathrm{~g}$ meat extract, $0.42 \mathrm{~g} \mathrm{NaHCO}_{3}$ and $0.53 \mathrm{~g}$ $\mathrm{Na}_{2} \mathrm{CO}_{3}$ per liter distilled water; $\mathrm{pH} 9.7$ ) and also in alkaline mineral medium supplemented with manganese to enhance sporulation (spore formation). The alkaline medium contained per liter of distillation water, $0.2 \mathrm{~g} \mathrm{NH} \mathrm{NH}_{4} \mathrm{Cl} 0.02 \mathrm{~g} \mathrm{KH}_{2} \mathrm{PO}_{4}$, $0.225 \mathrm{~g} \mathrm{CaCl}_{2}, 0.2 \mathrm{~g} \mathrm{KCl}, 0.2 \mathrm{~g} \mathrm{MgCl}_{2} \cdot 6 \mathrm{H}_{2} \mathrm{O}, 0.01 \mathrm{~g}$ $\mathrm{MnSO}_{4} \cdot 2 \mathrm{H}_{2} \mathrm{O}, 0.1 \mathrm{~g}$ yeast extract, $5.16 \mathrm{~g}$ citric acid trisodium salt, $4.2 \mathrm{~g} \mathrm{NaHCO}_{3}$ and $5.3 \mathrm{gNa}_{2} \mathrm{CO}_{3}$. were washed by repeated centrifugation and resuspension of the cell pellet in sterile tap water to harvest vegetative cells and spores but to remove dissolved culture constituents and residues. Obtained suspensions were microscopically analyzed to quantify the number of present bacterial spores by using a haemocytometer. The obtained clean spore suspension was subsequently diluted with the paste make up water to obtain a final cell density of $6 \times 10^{8}$ par ml.

strength after 3, 7, 28 and 90 days curing containing different organics representing potential bio-mineral precursor compounds. Concentration of added organics amounted to $1 \%$ of cement weight. Lactate was $0.5 \%$ of cement by weight. Ordinary Portland cement and water to cement weight ratio of 0.5 , for bacteria and organic compound amended samples was used for the preparation of the cement paste test specimens. Proportions of experimental mortar mixes are shown in table (1)

Table (1) Experimental Mortar Mixes Proportions

\begin{tabular}{|c|c|c|c|c|c|}
\hline No. & Sample & Sand/ cement & Water/ cement & $\begin{array}{l}\text { Bacteria } \\
\text { addition }\end{array}$ & Lactate \\
\hline 1. & Control & \multirow{3}{*}{$4: 1$} & \multirow{3}{*}{0.5} & 0.0 & non \\
\hline 2. & B. subtilis & & & $1 \%$ & $0.5 \%$ \\
\hline 3. & B. megaterium & & & $1 \%$ & $0.5 \%$ \\
\hline
\end{tabular}

\subsubsection{Reinforced Laminates}

Ferrocement laminates are $35 \times 10 \times 2 \mathrm{~cm}$. Each lamina has expanded wire mesh $35 \times 10 \mathrm{~cm}$ in mid height. Laminates were cast using three mortar mixes as shown in table (1). It was covered by wet cloth for 28 days. Ferrocement laminates were loaded on Flexural testing machine as shown in figure (1). They were loaded at mid-point until failure. Loaded span was $30 \mathrm{~cm}$. They were loaded until failure. Bacterial addition specimens were kept in wet environment for 2 months. Then, they were reloaded until failure. 


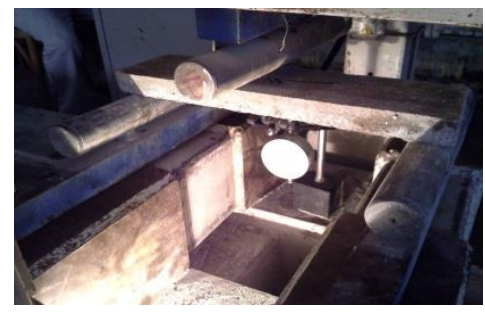

Figure (1) Flexure Test of Reinforced Laminates

\section{RESULTS}

\section{Spore formation and calcite production in liquid} cultures

All investigated bacterial species grew well in the specified sodium citrate-amended medium and produced copious spores during the late exponential growth phase. Moreover, all bacteria proved potent calcite producers in media amended with calcium chloride and a high concentration of sodium citrate but relatively lowinorganic carbon content. No calcite formation was observed in abiotic cultures (same medium but not inoculated with bacteria). Although both free calcium ions and inorganic carbon was present in this specific medium, no abiotic calcite formation occurred due to the calcium chelating efficiency of present citrate. Bacterial cultures did produce calcite, as metabolic conversion of citrate resulted in increased alkalinity and decreased chelating potential.

\section{Strength of bacteria and organic compound- amended paste specimens}

As organic additives to paste mixtures can result in unwanted strength loss, the effect of bacteria and organic compounds (potential bio-mineral precursors) on compressive strength was investigated. The cubes were tested on Hydraulic machine $2000 \mathrm{kN}$ capacity. Table (2) shows the compressive strength of the three mortar mixes used. The development of the compressive strength with time is shown in table (2).

Table (2) Compressive Strength of Mortar Mixes (N/ $\mathbf{m m}^{2}$ )

\begin{tabular}{|c|c|c|c|c|}
\hline \multirow{2}{*}{ Sample } & \multicolumn{5}{|c|}{ Age } \\
\cline { 2 - 5 } & 3 days & $\mathbf{7}$ days & 28 days & 90 days \\
\hline Control & 9.52 & 10.54 & 11.9 & 23.13 \\
\hline B. subtilis & 11.22 & 14.97 & 13.78 & 24.49 \\
\hline B. megaterium & 9.18 & 17.35 & 13.78 & 25.5 \\
\hline
\end{tabular}

Tests of reinforced laminates were conducted in the Properties of Material Laboratory, Civil Engineering Department, Faculty of Engineering, El-Menoufia University. Figure (2) shows LoadDeflection of Reinforced laminates for three mortar mixes. Reinforced laminates were tested under flexure after 28 days until failure. After testing, laminates with bacteria addition were covered with wet cloth and kept in the lab for two months. They were reloaded under flexure. Figure (3) shows a comparison between original and reloaded state for Load-Deflection of B. subtilis Laminates. Figure (4) shows a comparison between original and reloaded state for Load-Deflection of $\boldsymbol{B}$. megaterium Laminates. 


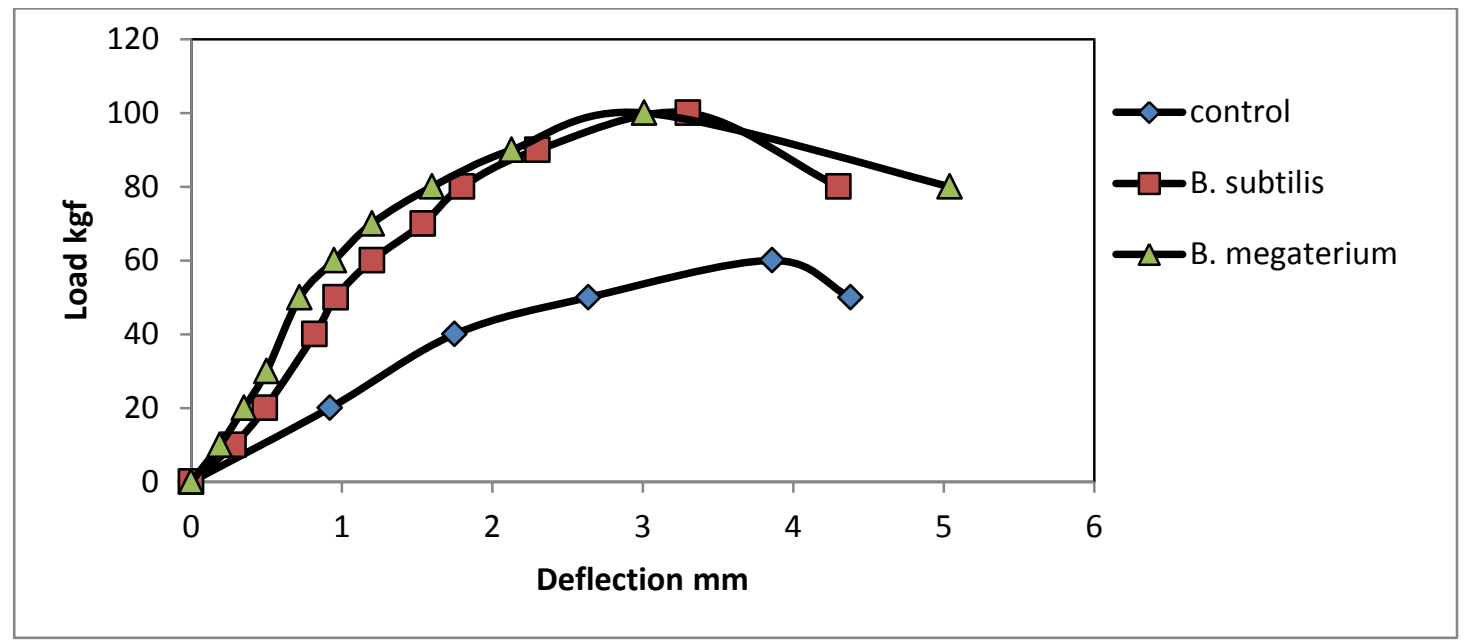

Figure (2) Load Deflection of Reinforced Laminates at 28 days

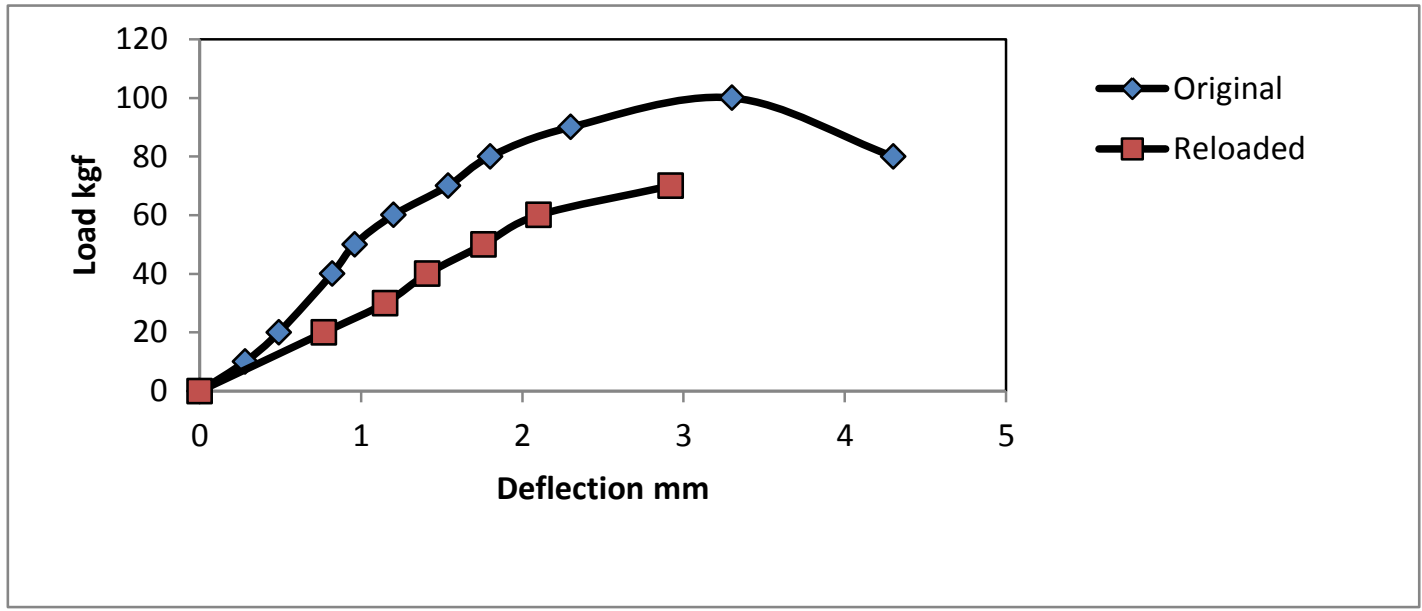

Figure (3) Load Deflection of B. subtilis Laminates

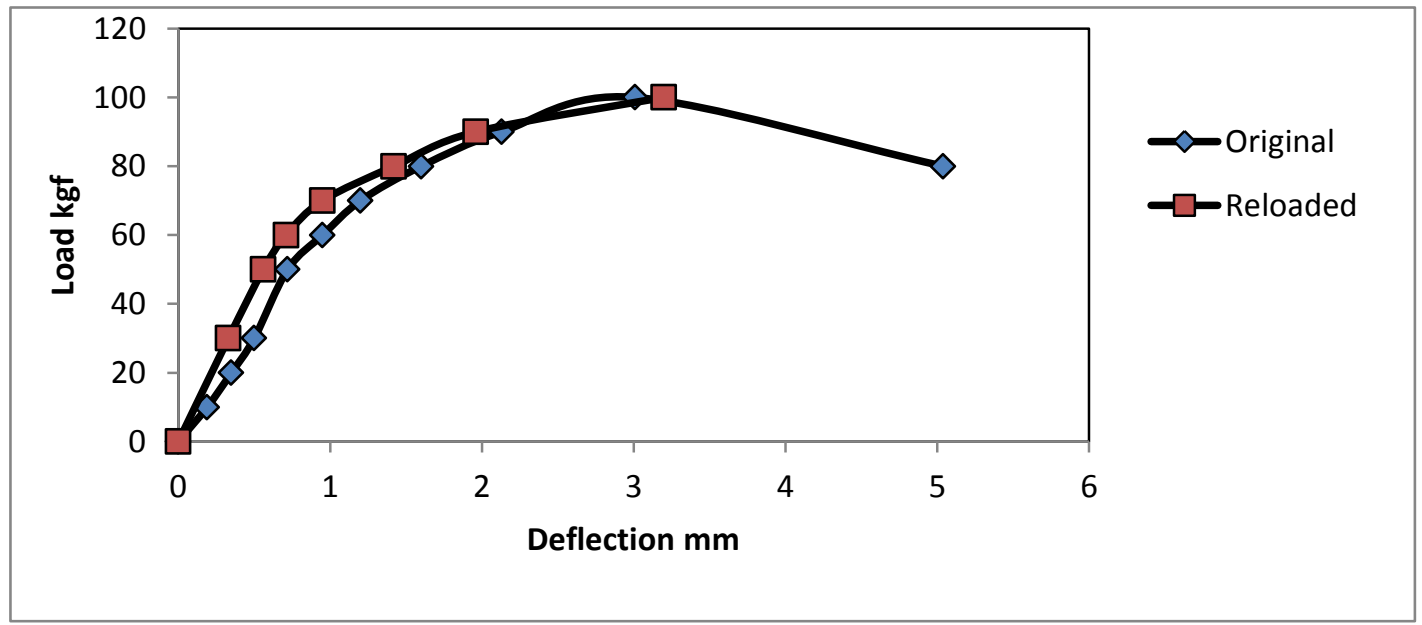

Figure (4) Load Deflection of B. megaterium Laminates 


\section{Calcite-producing potential of paste-immobilized bacteria}

Scanning Electron Microscope (SEM) analysis of the surface of 28days loaded paste samples showed major differences between control (no additions) and calcium lactate plus bacteria-amended specimens as shown in figures (5, 6, 7, 8 and 9).

Each sample was slicked on metallic blocks by using silver paint. Samples were evenly gold coated in a thickness of $15 \mathrm{~nm}$ by using gold sputter coating apparatus (JFC-1100E).Sample were examined by using JEOL 5400 L.V scanning electron microscope at $15-25 \mathrm{kv}$ and photographed in Assiut Electronic Microscope Unit.

The three mortar mixes were compared using SEM pictures at the same magnifying. Voids in the cement paste mixes are shown in figure (5) at magnifying X100. Control mix has many voids compared with $B$. subtilis mix and B. megaterium mix on the fracture plan.

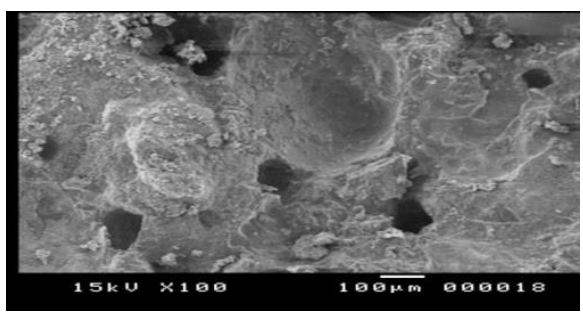

5.a. Control Mix

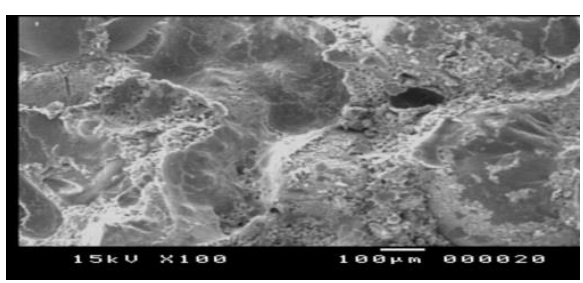

5.b. B. subtilis

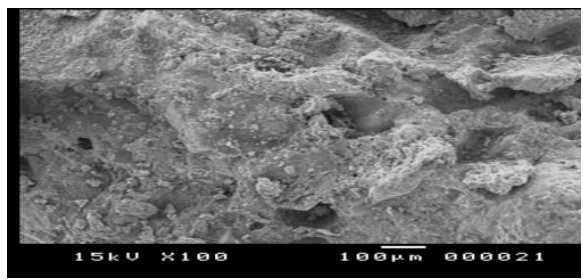

5.c. B. megaterium

Figure (5) SEM of Cement Paste Samples (X100)
Higher magnifying of X1500 is shown in figure (6). Figure (6.a) shows control specimen has an obvious continuous crack. Figure (6.b) has many cracks and needle shaped are growing and crossing between cracks. Figure (6.c, 6.d) has many cracks flower shaped are growing and crossing between cracks. Figure (7.a) shows aggregation of control specimen. It has a lot of voids. Figure (7.b). B. subtilis specimen has needle shaped bridging cracks. Figures (7.c, 7.d) of B. megaterium have many cracks flower shaped creating plans crossing crack. The new shapes in non-cracked phase make good sealing of the outer portion.

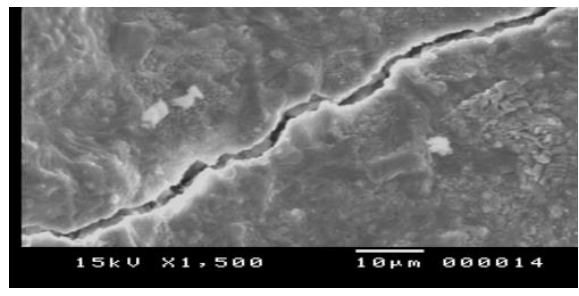

6.a. Control Mix

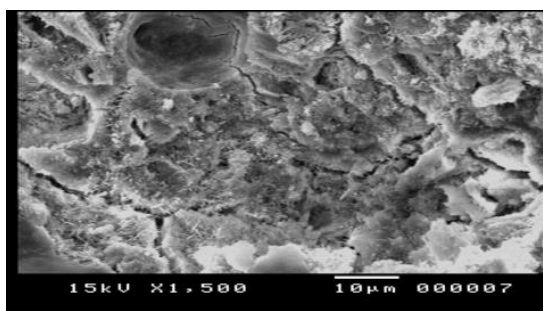

6.b. B. subtilis

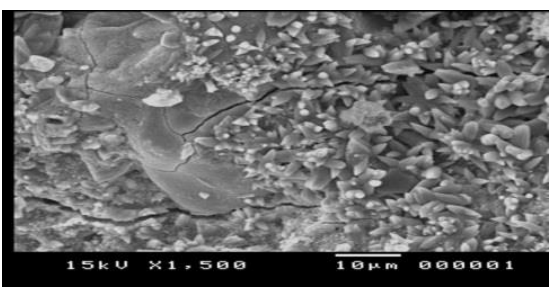

6.c. B. megaterium

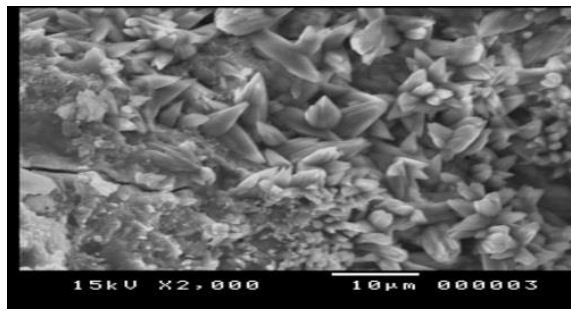

6.d. B. megaterium

Figure (6) SEM of Cement Paste Samples (X1500) 


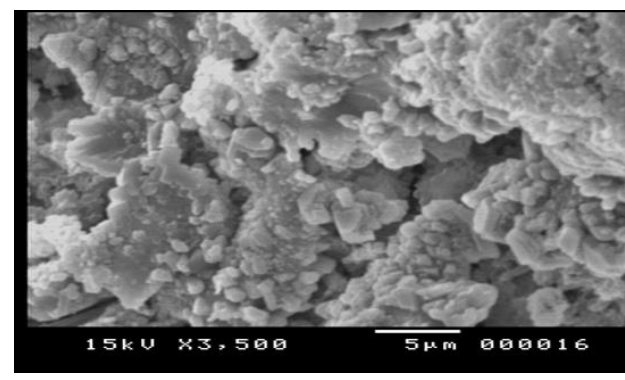

7.a. Control Mix

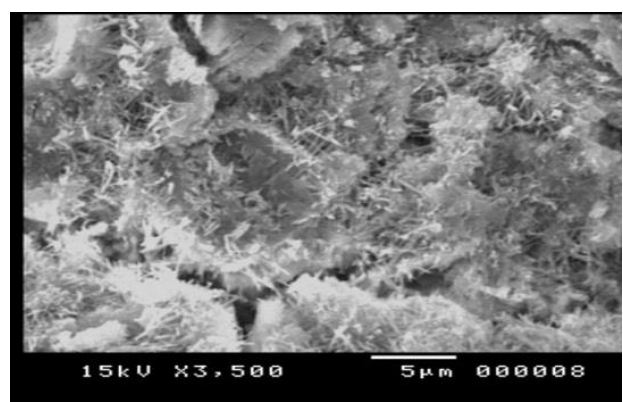

7.b. B. subtilis

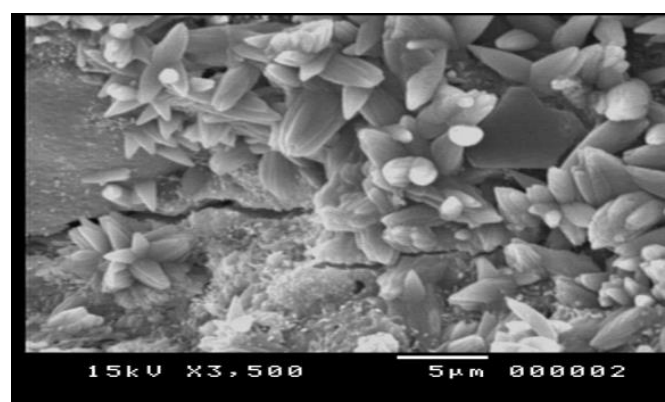

7.c. B. megaterium

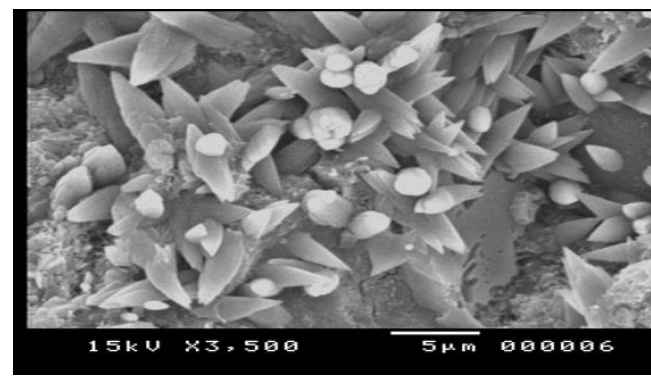

7.d. B. megaterium

Figure (7) SEM of Cement Paste Samples (X3500)

Figure (8) is higher magnification X5000 of the experimental specimens. Control test specimen $2 \mu \mathrm{m}$ Crack width has clear open void as shown in figure (8.a). Many healed cracks of B. subtilis are shown in figure (8.b). Needle shapes of $B$. subtilis makes bridges between crack plans. Figure (9) is X7500 magnification of specimens. The needled shapes of B. subtilis are very obvious in figure (9.b, 9.c, 9.d). Flower shaped of $B$. megaterium are very clear in figure (8.c). B. megaterium shapes seem to have higher bond than that of B. subtilis. Flower shaped makes plans to cross the crack, while needle shapes are more like sticks. Needle shaped of B. subtilis seems to be weaker than that of flower shaped of $B$. megaterium.

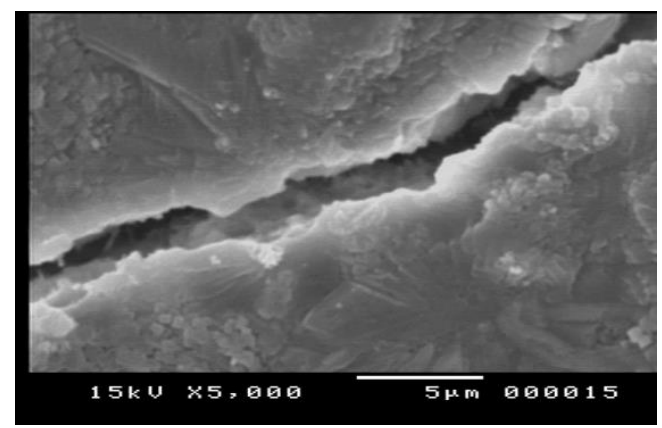

8.a. Control Mix

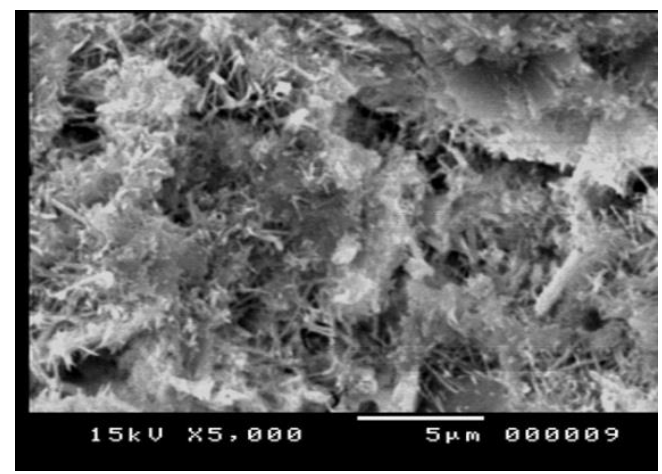

8.b. B. subtilis

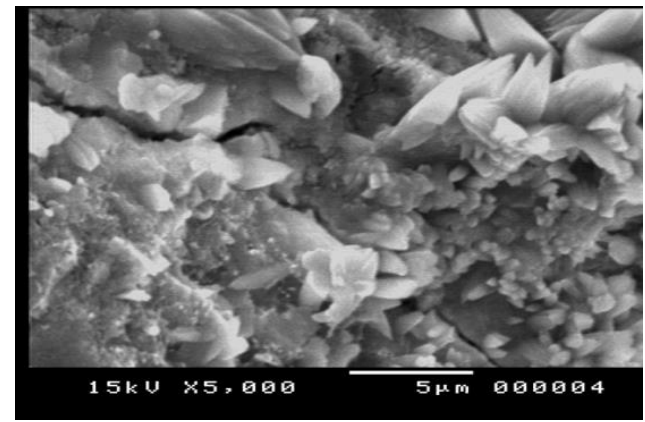

8.c. B. megaterium

Figure (8) SEM of Cement Paste Samples (X5000) 


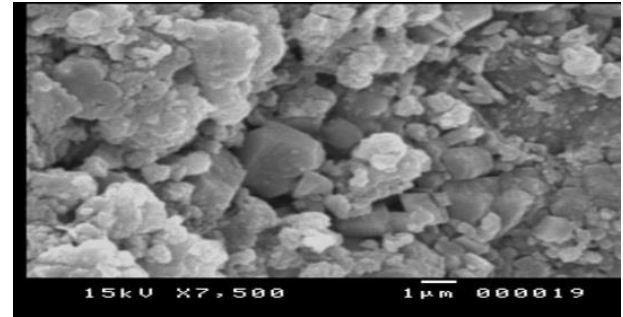

9.a. Control Mix

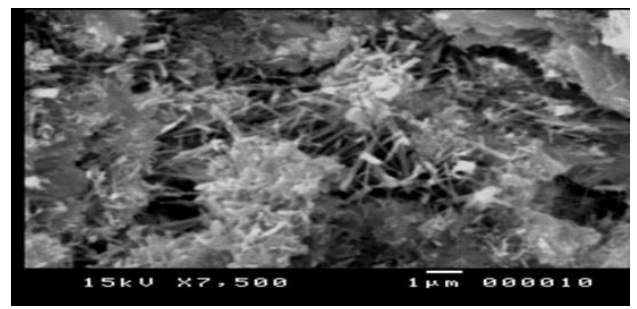

9.b. B. subtilis

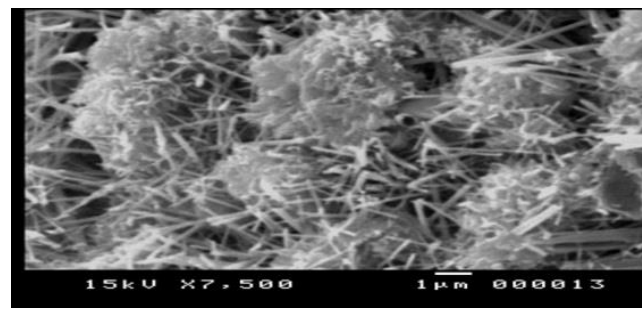

9.c. B. subtilis

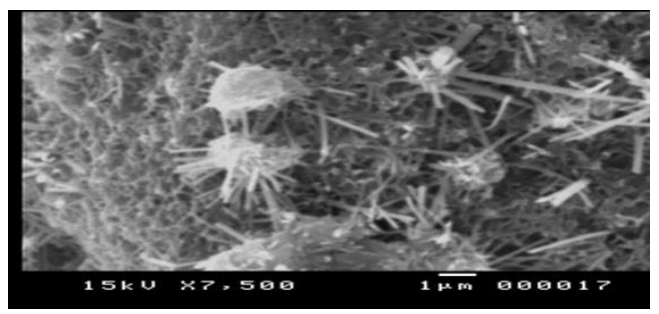

9.d. B. subtilis

Figure (9) SEM of Cement Paste Samples (X7500)

\section{Discussion}

Bacteria stimulate a bio-chemical process in concrete, which works as an agent. The biochemical agent consists of a mixture of bacteria and calcium lactate. This agent is activated by water calcium carbonate-based minerals through metabolic conversion of calcium lactate. The minerals produce blocks and seal cracks, which may

Incorporation of bacteria in the paste resulted in 42 , $65 \%$ increase for B. subtilis and B. megaterium in compressive strength as values amounted (compared with control mix) after 7days curing respectively as shown in table (2). Bacteria resulted in $16 \%$ increase for B. subtilis and B. megaterium in result in a delay of water ingress. Sealed concrete sections decrease the diffusion rate of chloride and oxygen. The metabolically active bacteria consume oxygen. The agent may act as an oxygen diffusion protecting the embedded steel reinforcement against corrosion. In this manner the reinforcement will be protected for longtime, where a lack of oxygen prevents corrosion. Bacteria incorporation in concrete would be cheap. It is easy when the agent is stable prior to the addition to concrete. The proposed sustainable bio-chemical healing agent application will result in a substantially decreased maintenance and repair costs of steel reinforced concrete structures. Bacterially produced minerals large cracks could potentially be healed. Bacterially induced self-healing mechanism based on the metabolic conversion of suitable organic compounds to calcite, e.g. represented by the bioconversion of calcium-formate with portlandite present in the paste matrix:

$$
\mathrm{Ca}\left(\mathrm{CHO}_{2}\right)_{2}+\mathrm{Ca}(\mathrm{OH})_{2}+\mathrm{O}_{2} \rightarrow 2 \mathrm{CaCO}_{3}+2 \mathrm{H}_{2} \mathrm{O}
$$

Bacteria are applied for durability improvement or concrete repair. Calcite production potential of bacteria (B. subtilis and B. megaterium) and their applicability to concrete was employed.

Both bacteria and mineral precursor compounds were mixed with the paste and became an integral part of the material. Bacteria survive within the concrete matrix and activated by a combination of (ingress) water. The extent of bio-availability of organic compounds mixed with the cement paste is $1 \%$ bacteria and $0.5 \%$ lactate proved to be sufficient.

Addition of healing agents such as bacteria and organic chemical compounds (lactate) to the paste results in strength properties fluctuation. Compressive strength gain due to incorporation of bacteria ( $B$. subtilis and $B$. megaterium) was observed. Strength increase is compensated by a substantial increase in the materials self (crack)healing capacity. The two-component self-healing system tested (incorporated bacteria plus calcium lactate) resulted in the formation of $2 \mu \mathrm{m}$ sized calcite particles on specimen surfaces in contrast to controls much smaller sized particles were formed. Two-component system may be characterized crack-healing potential, as larger calcite particles are produced.

compressive strength as values amounted (compared with control mix) after 28days curing respectively. Bacteria resulted in $6,10 \%$ increase for B. subtilis and B. megaterium in compressive strength as values amounted (compared with control mix) after 90days curing respectively. 
Self-healing with the aid of incorporated bacteria could result in a better healing (sealing of larger cracks) compared to autogenous healing of nonamended pastes. Low water to cement weight ratio has an extra substantial self-healing capacity. This may be due to the large amount of partially unhydrated cement particles present in the material matrix. Such particles will undergo secondary hydration in wet environment. The capacity of this autogenous chemical self-healing mechanism is directly related to the amount of unhydrated cement particles present in the material matrix.

Compressive Strength: Un-hydrated cement particles are present in the crack. Storing the specimens in water probably opens the way to further hydrate this cement in the crack. Control mix has an ascending gain of compressive strength. Specimens were kept in wet environment for 90days. The high gain of compressive strength is due to low w/c ratio and high cement content, which caused partial cement hydration. Continuity of curing hydrated the residual resulting in an increase of compressive strength. As for bacteria addition, a full consumption of lactate besides unhydrated cement particles in early ages may cause compressive strength gain at first week. Later, bacteria depended on unhydrated cement particles.

Laminates: In the bulk material water cannot reach these un-hydrated particles. This means that concrete with OPC probably has some more capacity for crack healing at later stages. If first crack takes place at late ages, a decrease in strength recovery is found. The amount of hydration that still can take place is fixed. The amount of strength recovery is therefore also limited when the concrete has already reached a higher degree of hydration when the crack is made. Reloaded specimens have a high restoration. Specimen in the original state is more ductile than that of reloaded specimens. Restoration of Bacillus subtilis is $70 \%$ of the original state as shown in figure (3). It is very good for specimen loaded until failure. This means $100 \%$

\section{References}

1.Thijssen, A., Muyzerb, G., Copuroglua, O., Schlangena, E., (2010), "Application of Bacteria as Self-healing Agent for the Development of Sustainable Concrete", Ecological Engineering, Vol. 36, pp.230-235

2.Jonkers, H.M., (2011), "Bacteria-based Selfhealing Concrete". HERON Vol. 56 pp. 1-12.

3. Wool, R.P. (2008), "Self-healing Materials: a Review", The Royal Society of Chemistry, Vol. 4, pp.400-418. restoration may be gained for moderate loads. Full recovery of specimen cracks is expected under $67 \%$ of ultimate load. Reloaded specimen of Bacillus subtilis addition had brittle failure. Restoration of B. megaterium is $100 \%$ of the original state as shown in figure (4).This means full recovery with brittle failure. Those are very promising results.

Figure (5.a) shows control specimen has many gaps or holes on the fracture plan compared with figure (5.b, 5.c). Figure (6.a) shows control specimen has an obvious continuous crack. Figure (6.b) has many cracks and needle shaped are growing and crossing between cracks. Figure (6.c, 6.d) has many cracks flower shaped are growing and crossing between cracks. Figure (7.a) shows aggregation of control specimen. It has a lot of voids. Figure (7.b) Bacillus subtilis sample has needle shaped bridging cracks. Figure (7.c, 7.d) has many cracks flower shaped creating plans crossing crack.

\section{Conclusion}

1. A high crack-healing potential of concrete structures is beneficial as it makes the material stronger and more durable.

2. A continuous healing reduced risk significantly of premature matrix degradation and corrosion of the embedded steel reinforcement due to ingress water and aggressive chemicals.

3. Cement paste with high cement content, i.e. based on a low water/cement ratio; feature a significant autogenous crack-healing capacity. Unhydrated cement particles undergo full hydration during lifetime to improve the durability.

4. Self-healing may approach non-cracked structures, which enhances durability of concrete structures.

5. Self-healing materials are inherently sustainable. Self-healing materials reduce maintenance costs and enhances the life span of structures.

4. Bommavaram, R.R., (August 2008), "Evaluation of Healing in Asphalt Binders Using Dynamic Shear Rheometer and Molecular Modeling Techniques". MSc. thesis, Texas University, 95pages.

5. García, A., Schlangen, E., Ven M.V., Vliet D., (2011), "Crack Repair of Asphalt Concrete with Induction Energy", HERON Vol. 56, No. 1, pp.33-44.

6. Lubelli, B., Nijland, T.G., Hees R.P., (2011), "Self-healing of Lime Based Mortars: 
Microscopy Observations on Case Studies". HERON Vol. 56 pp.75-92.

7. Jonkers, H.M., Schlangen, E., (2008), "Development of a Bacteria-Based SelfHealing Concrete", Taylor \& Francis Group, pp.425-430.

8. Breugel, K., (2007), "Is There A Market for SelfHealing Cementbased Materials?" Proceedings of the $1^{\text {st }}$ International Conference on SelfHealing Materials, 18-20 April 2007, Noordwijkaan Zee, The Netherlands.pp.13-21.

9. Yang, E., (2008), "Designing Added Functions in Engineered Cementitious Composites". Ph.D. Thesis. The University of Michigan, 293page.

10. Aissa, B., Therriault, D., Haddad, E. and Jamroz, W., (2012), "Self-Healing Materials Systems: Overview of Major Approaches and Recent Developed Technologies", Review Article, Advances in Materials Science and Engineering, 17 pages
11. Heide N., and Schlangen, E., (2007), "Selfhealing of Early Age Cracks in Concrete", Proceedings of the $1^{\text {st }}$ International Conference on Self-Healing Materials, 18-20 April 2007, Noordwijkaan Zee, The Netherlands. pp. 1-12.

12. Yurdakul, E., (2010), "Optimizing Concrete Mixtures with Minimum Cement Content for Performance and Sustainability", M.Sc thesis, Iowa State University. Pages112.

13. Fikru, N., (2009), "Self-Healing of Fiber Reinforced Polymer Compoistes", M.Sc. Thesis, Agricultural and Mechanical College, Faculty of the Louisiana State University, 75pages.

14. Sangadji, S., and Schlangen E., (2013), "Mimicking Bone Healing Process to SelfRepair Concrete Structure Novel Approach Using Porous Network Concrete". Procedia Engineering Vol.54, pp.315-326 